\title{
Factors of Using Non-Cash Payments to the Consumption Level of Students
}

\author{
Yerisma Welly \\ Universitas Negeri Medan \\ welly.yerisma@gmail.com \\ Supitriyani \\ Program Studi Akuntansi, Sekolah Tinggi Ilmu Ekonomi Sultan Agung \\ supitriyani@stiesultanagung.ac.id \\ Yusnaini \\ Universitas Sriwijaya \\ yusnaini@fe.unsri.ac.id \\ Acai Sudirman \\ Sekolah Tinggi Ilmu Ekonomi Sultan Agung \\ acaivenly@stiesultanagung.ac.id
}

\section{Suggested Citation:}

Ming, W. et al. (2016) 'Factors Affecting Consumers' Perception of Electronic Payment: an Empirical Analysis', Internet Research, 23(4), pp. 465-485.

\begin{abstract}
:
This study aims to determine the factors of the use of non-cash payments to the consumption levels of Pematangsiantar City students. The population in this study were students of Accounting Department in the seventh semester at STIE Sultan Agung Pematangsiantar as many 167 people. This study used quantitative data in the form of a questionnaire. Data analysis techniques used in this research are classic assumption test, multiple linear regression, determination test, $F$ test and $t$ test. The results showed that the perceived usefulness, perceived ease of use and perceived trust had a positive and significant effect on student consumption levels. This is because students prefer to make any purchases (consumption) using non-cash payments. The benefits of non-cash payments can be used anywhere, easy to carry, more secure and has trust in the accuracy of the transactions made.
\end{abstract}

Keywords: consumption level, perceived usefulness, perceived ease of use, perceived trust

JEL Classification: M31 


\section{Introduction}

Indonesia has been in the era of the industrial revolution 4.0 that demands internet of thing and does not close the possibility of Indonesia to the Society Era 5.0. So the use of information and communication technology will be an integral part of human life to support daily activities. One of the characteristics that reflects the impact of the development of information technology is the rapidly growing use of the internet (Hasibuan et al., 2020). The era internet of thing impacts on the current payment systems, as we have seen slowly shifting from cash payments into non-cash payments. Where the use and electronic payments in other countries such as Malaysia have been found in many banking companies, online payer service providers, and software developers (Ming et al., 2016).

At this time to change the mindset and habits of customers is not easy, especially when the service is associated with cash payments while cash payments are still the most popular of money transfer (Lin and Nguyen, 2011). The more dominant electronic payment system offers convenience and flexibility to customers who want to do digital transaction online (Acheampong et al., 2017). Non-cash payments are made without using money as means of payment, but by way of transfer between banks or intra banks through the internal networks of the bank themselves (Wasiaturrahma, Wahyuningtyas and Ajija, 2019).

The emergence of this financial application innovation also supports non-cash transactions, which function as electronic money which is now widely used in Indonesia such as Link Aja, Ovo, Gopay, DANA, e-toll, YAP, Sakuku and others. In addition, there is also which is a mobile social banking application that provides serverbased electronic money services and smart behaviour services. These financial innovations make it easier for people to transact so that the more use of non-cash payments system will benefit the increase in efficiency and financial productivity. This of course will encourage real sector activity that increases the economic value and welfare of society in general. This statement supported in the research of Rukmana (2016), it is said that the emergence of financial reforms, namely the renewal of the cash payment system into non-cash payments, is a breakthrough in the advancing technological advancements. The development of the payment system has led to an increase in the value of transactions carried out by the public.

Bank Indonesia $(\mathrm{BI})$ recognizes the era of digital technology or the era of the industrial revolution 4.0 has provided a new alternative in payment transactions. In the past, people only knew about payment transactions using ATM / debit cards, now people also know about payment transactions through electronic money, mobile phones, QR code payments, and RFID. The growth of internet banking industry is demonstrated by using internet banking. Presence with this system provides convenience for customers in manage and enjoy their bank transaction need (Ronny, 2018). As said by the Head of the BI Payment System Policy Department, Onny Widjanarko, the many new alternative payment systems have shifted the behaviour or habits of people in making transactions, especially using cash (Warta Ekonomi, 2018). Since 2014, Bank Indonesia has launched Gerakan Non Tunai (GNT) in Indonesia. The government is quite aggressive in carrying out activities to launch this Gerakan Non Tunai, including the payment of government transactions such as payment of salaries, taxes, fees, and others. Program Keluarga Harapan (PKH) and Bantuan Pangan Non Tunai (BPNT) is also carried out in collaboration with a State-Owned Commercial Bank. In addition, the government has also launched non-cash payments in the transportation sector such as toll roads, commuter trains, Transjakarta buses, parking and others.

Most people at this time already know about Industrial Revolution 4.0, even though it might be just knowing from a cursory reading news related to evolution /transformation (Rumondang et al., 2019). Lintangsari (2017), said the development of the value of non-cash payment transactions has increased from year to year, especially with the support of technological developments and lifestyle changes in society. This has resulted in more and more non-cash payment system innovations in Indonesia. In addition, practicality is the most important factor that is much sought after by the public, which in turn encourages banks to continue to innovate banking products in meeting the needs of the community. In Jati (2015) research, it was explained, a study of consumption in the middle category events in Indonesia passed a community chart using non-cash which created some attractive findings. First is technology that has an important role in increasing middle class consumption in Indonesia to be more consumptive. Second is the use of technology for the use of consumption through electronic money which provides a new level of consumption use. Consumption is not only used for its benefits but also the role of identity that needs to be fulfilled. Technological development which is followed by an increase in consumption gives a considerable influence on the composition of new consumption which prioritizes the perspective of external goods in order to obtain recognition and representation as a factor of modern society. This assumption is 
then embedded in non-cash transactions to prove that consumption is a factor of efforts to strengthen the superiority of the community class and can maintain group relations.

The author chose students of Accounting Department in the seventh semester at STIE Sultan Agung Pematangsiantar city of economics as the object of research because the authors assume that Pematangsiantar City is a city that has developed that contains various levels and order of modern society who wants speed in providing goods as a form of availability of goods they will consume. In addition, Pematangsiantar City is one of the cities that have a good level of education in North Sumatra. Therefore, the ability to use electronic money offered by Bank Indonesia will not be too difficult for the public to apply in everyday life. On the other hand, Pematangsiantar City is also one of the largest cities in North Sumatra which can be a strong basis for increasing the consumption power of its people.

\section{Literature Review}

\section{TAM (Technology Acceptance Model)}

According to Davis (1989), TAM has the main objective of providing a presentation and explanation of the acceptance of computers as well as providing an explanation of the protection of certain users (Sayekti and Pulasna 2016). TAM describes the construction of external variables that affect construction that is perceived ease of use and construction that is felt to be beneficial. Whereas the construction (perceived ease of use and perceived usefulness) are both about construction of use. The intention of the construction to use will be considered by the perceived usefulness and the behavioral intention to use also by the construction of the attitude towards the use will also affect the actual use.

\section{Perceived Usefulness}

In Davis Research (1989) stated that users have confidence that if you use information systems it will improve performance. That is, the perception of usefulness will produce a trust to make decisions using information systems or not using information systems. The user will think and believe that if the system is useful for him then he will use it, but conversely if the user does not believe that the system is not useful for him then the user will definitely not use the system.

\section{Perceived Ease of Use}

According to Davis (1989), perceived ease of use is the level where individuals believe about the system used because the system is easy to use and easy to understand, so no need to spend any effort (free of effort). Sun and Zhang in Wibowo, Dede, and Usep (2015), identify the dimensions of perceived that is easy to learn, easy to use, clear and understandable, and become skillful.

\section{Perceived Trust}

According to Lau and Lee (1999) trust is interpreted in the form of an individual's willingness to depend on other individuals in the presence of a certain risk. Willingness will arise because the individual understands the other party based on his past, the other party's expectations that arise will make a positive contribution (there is a possibility of a negative contribution made from another party).

\section{Non-cash payment instruments}

Non-cash payment instruments are transactions for which payments are not made using cash, but instead use cash as a means of payment. The intended cash replacements such as, checks, giro, credit cards, debit cards and electronic money (Bank Indonesia, 2019).

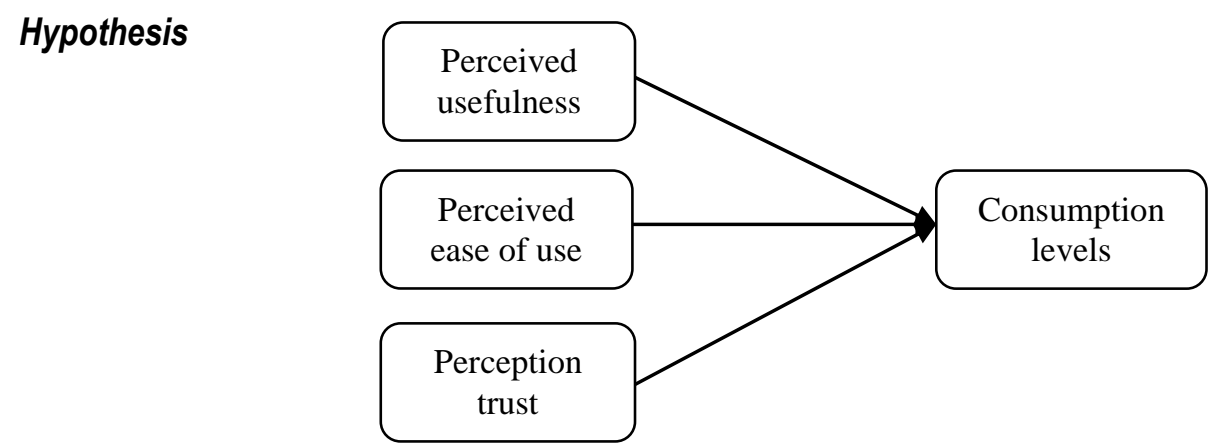

Figure 1. Research Framework 
H1: Perceived usefulness has a positive effect on consumption levels

H2: Perceived ease of use has a positive effect on consumption levels

H3: Perception trust has a positive effect on consumption levels

\section{Methodology}

This research was conducted in Pematangsiantar City by using quantitative research methods. Quantitative data used in this study were sourced from secondary data summarized in the form of questionnaires. Population in this research students of Accounting Department in the seventh semester at STIE Sultan Agung Pematangsiantar city. The total number of the population is 167 students. In this study, to examine the factors of using non-cash payments to the consumption level of students in the city of Pematangsiantar is to look at the factors that influence them such as perceived usefulness (X1), perceived ease of use (X2) and perceived trust (X3) of consumption level $(Y)$.

\section{Result}

\section{Multiple Linear Regression Analysis}

Based on the classic assumption test that has been done shows that this research model has met the requirements of normally distributed and free from heteroscedasticity. The multiple linear regression equation implies that in a regression equation there is one dependent variable and more than one independent variable. This study aims to determine the effect of the independent variable perceived usefulness (X1), perceived ease of use $(X 2)$, and perceived trust $(X 3)$ on the dependent variable consumption level $(Y)$. Regression analysis results obtained $\hat{Y}=4.512+0.811 X 1+1.324 X 2+0.387 X 3$. This means that perceptions usefulness, ease of use and trust have a positive influence on consumption levels.

\section{Determinant Coefficient}

Testing the coefficient of determination $(R)$ to measure how far the ability of the factors using non-cash payments in explaining the level of consumption of Pematangsiantar City students. The obtained $\mathrm{R}$ Square Adjusted value of 0.435 , indicating $R$ away from 1 . R2 value away from 1 means that there is a relationship between the variables of perceived usefulness, perceived ease of use and perceived trust in the level of consumption. Overall the factors of using non-cash payments in the study can explain its effect on the level of student consumption in Pematangsiantar City by $66.8 \%$ and the remaining $33.2 \%$ is explained by other factors not included in this research model.

\section{Hypothesis Testing Simultaneous Test (F Test)}

Based on the simultaneous test ( $F$ test), it was carried out in this study to find out the statistically significant effect between the factors of using non-cash payments, namely the variable of perceived usefulness, perceived ease of use and perceived trust together with the level of student consumption in the Pematangsiantar city. $F$ test results can be seen the $F$ value of 38,165 with a significance of 0,000 where the significance value is smaller than alpha $(0,000<0.05)$ which means the null hypothesis is rejected. Means that variable of perceived usefulness, perceived ease of use and perceived trust simultaneously have a significant effect on consumption level.

\section{Partial Test (t test)}

The regression coefficient test ( $t$ test) aims to test whether the independent variable (perceived usefulness, perceived ease of use and perceived trust) of the dependent variable (student consumption level) has a partial or separate effect. In seeing whether the influence of the independent variables on the dependent variable can be known by looking at the probability of significance.

Based on the results of testing the hypothesis in this study, we obtained a regression coefficient of perceived usefulness variable of 0.811 , ease perception variable of 1.324 and confidence perception variable of 0.387 indicates the direction of positive regression coefficient with a significance value of $0.006,0.000$, and 0.011 . At the error level (alpha) 0.05 can be said to have a significant effect because the significance value of the three variables has a value that is smaller than the error rate $(0.006<0.05,0.000<0.05$ and $0.011<0.05)$. This means that the factors of using non-cash payments, namely perceived usefulness, perceived convenience and 
perceived trust affect the consumption level of Pematangsiantar City students so that the first, second and third hypotheses in this study can be supported.

\section{Discussion}

This research is a study that analyzes the effect of perceived usefulness, perceived ease of use and perceived trust on student consumption levels in Pematangsiantar City. The following explains the effect of each variable on the level of student consumption in Pematangsiantar City based on the results of tests that have been carried out through SPPS version 21.

\section{The Influence of Perceived Usefullness Variable on Students Consumption Level Variable in Pematangsiantar City}

The results showed that the perceived usefulness had a positive and significant effect on consumption levels, which means that if the benefits of using non-cash payments were obtained high, the consumption level would also increase. This is in line with research by Aksami and Jember (2019) which shows that the aspect of benefits has a positive and significant effect on the interest in using e-money services. This means that if the benefits obtained are high, the interest in using e-money services will increase thereby increasing public consumption. On the other hand, the results of this study are in contrast with Setiani (2018) which stated that the perceived usefulness does not significantly influence the use of non-cash payment instruments. Utilization can serve as a benchmark for the number and variety of applications used. The increasing variety of applications or facilities for non-cash payment instruments used by the community proves that technology has high benefits that can be felt by the people who use the application or non-cash payment tools.

\section{The Influence of Perceived Ease of Use Variable on Students Consumption Level Variable in Pematangsiantar City}

The results showed that perceptions ease of use had a positive and significant effect on consumption levels, which means that if the ease of using non-cash payments is obtained high, consumption levels would also increase. This is in line with research by Aksami and Jember (2019) which shows that the ease of use aspect has a positive and significant effect on the interest in using e-money services, which means that if the ease of use is obtained, the interest in using e-money services will increase. On the other hand, the results of this study are in contrast with Setiani (2018) which stated that the perception ease of use does not significantly influence the use of non-cash payment instruments. The community considers that how to use an application or non-cash payment tool is not difficult to understand and does not require business because it can be used anywhere without being limited by the distance and time as long as the application or the use of non-cash payment facilities are available.

\section{The Influence of Perceived Trust Variable on Student Consumption Level Variable in Pematangsiantar City}

The results show that the perceived trust has a positive and significant effect on consumption levels, which means that if the trust in the use of non-cash payments is obtained high, the level of consumption will also increase. This is in line with Setiani (2018) which stated that trust has a positive and significant effect on the use of non-cash payment instruments. Setiani (2018) has proven that a person's level of trust in using technology has a positive influence on one's attitude in using non-cash payment instruments. That is, the increasing level of someone's trust in using technology, the person's attitude will be stronger in using this non-cash payment instrument. Chawla (2019), research which states that trust in using mobile wallet in India is formed from several factors such as perceived ease of use, perceived usefulness, and security. This statement is supported by research carried out Kesharwani \& Shailendra (2012), that trust has a negative impact on internet banking adoption.

\section{The Influence Factors of Using Non-Cash Payments to the Consumption Level of Students in Pematangsiantar City}

The results showed that the factors of using non-cash payments had a positive and significant effect on consumption levels. There is a positive and significant relationship between the use of non-cash payments on student consumption expenses, especially the Accounting Students Seventh Semesterof STIE Sultan Agung 
Pematangsiantar City. But the use of non-cash payments can have a negative impact because it will indirectly make the students more consumptive. Because non-cash payments make the student consumption activities more effective and efficient. Nowadays the use of non-cash payments is like a life style for the community. For example the use of Link Aja, Ovo, Gopay, DANA, e-toll, YAP, Sakuku, debit cards, ATM cards and other noncash payments is a trend among students as a means of consumption with various facilities that allow users to get the ease of making easy cash withdrawal, easy payment of various types of bills and various facilities that pamper users, namely the presence of discounts, cashback, vouchers, points that can be exchanged for gifts and other rewards.

A person's consumption patterns basically begin to form from adolescence. At this age a person is in a transition period where habits begin to form, including consumption habits. Because adolescent's unstable nature makes him tend to consume with less rational reasons such as being influenced by advertisements from various media, imitating friends, as well as wasteful tendencies (Wagner, 2009). This consumptive behavior makes teenagers as well as students to spend their money excessively so that student consumption expenditure will increase. The use of non-cash payments is one of the factors that influence student consumption expenditure, where the higher the use of non-cash payments by students, the student consumption expenditure will also increase. This is because psychologically, a person will be more easierto spend money in the form of non-cash than cash. This is not a matter of technology, but human trade behavior over money as a physical and nonphysical instrument. There are different consumption behaviors between cash and non-cash payments. Consumers make cash payments to buy goods or services that are needed daily. In cash transactions, consumers focus on the cost or the amount of money spent. Meanwhile, consumers make non-cash payments to purchase goods or services that are pleasing to them (Ramadani, 2016).

\section{Conclusion, Implication, Suggestion, and Limitations}

From the results of the research and discussion, it can be concluded as follows: The results of perceived usefulness variable testing shows that usefulness has a positive and significant effect to the consumption level of students in Pematangsiantar City. The results of perceived ease of use variable testing shows that ease of use has a positive and significant effect to the consumption level of students in Pematangsiantar City. The results of perceived trust variable testing shows that trust has a positive and significant effect to the consumption level of students in Pematangsiantar City. The factors of using non-cash payments, namely perceived usefulness, perceived convenience and perceived trust has a positive and significant effect to the consumption level of students in Pematangsiantar City because students prefer to make any purchases (consumption) using non-cash payments. The benefits of non-cash payments can be used anywhere, easy to carry, more secure and has trust in the accuracy of the transactions made.

Based on the above conclusions, the suggestions to be submitted from this study are as follows: For Students, are advised to be wiser in using non-cash payment facilities so that the non-cash payment instruments can be usefulness as well as possible and provide ease of use and trust in using these facilities. For general, the presence of non-cash payment instruments can eliminate obstacles in the use of physical payments and has the potential to encourage an increase in consumption levels.

This study has limitations and suggestions that might affect the results of the research are as follows: In this research is only limited to students of accounting department in the seventh semester at STIE Sultan Agung Pematangsiantar as many 167 respondents which are still considered too small compared to the number of students who use non-cash payment instruments in Pematangsiantar city. So, it is still unclearly visible the difference from the use of non cash payment instruments. For further research, it is suggested to increase the number of samples and choose other locations or places of research so that the scope of research can be wider. In this research, researchers only examined 3 variables, namely perceived usefulness, perceived ease of use and trust, so they could not include and know all the variables that influence students behavior in using non-cash payment instruments. For further researchers are suggested to expand the study by using other factors of using non-cash payments to the consumption level, such as risk perception, technological innovation, promotional.

\section{References}


Acheampong, P. et al. (2017) 'Hybridizing an Extended Technology Readiness Index with Technology Acceptance Model ( TAM ) to Predict E-Payment Adoption in Ghana', American Journal of Multidisciplinary Research, 5(2), pp. 172-184.

Aksami, Ni Made Dwi, Jember, I Made. (2019). Analisis Minat Penggunaan Layanan E-Money Pada Masyarakat Kota Denpasar. E-Jurnal Ekonomi Pembangunan Universitas Udayana. Volume 8, Nomor 9, Oktober.

Chawla, D., \& Joshi, H. (2019). Consumer attitude and intention to adopt mobile wallet in India - An empirical study. International Journal of Bank Marketing, IJBM-09-2018-0256. https://doi.org/10.1108//JBM-092018- 0256.

Davis, F. D., Bagozzi, R. P., \& Warshaw, P. R. (1989). User Acceptance of Computer Technology: a Comparison of Two Theoretical Models. Management Science. Aug1989, 35(8), 982-1003.

Fajrian, Hilman. (2015). "30\% Lebih Boros Dengan Non Tunai". (http://www.kompasiana.com/hilmanfajrian/30lebihborosdengannontunai_55711ada2523bdf632584818). Diakses 10 Nopember 2019. https://www.wartaekonomi.co.id/read178529/industri-40-geser-perilakutransaksi-pembayaran.html. Diakses pada tanggal 10 Nopember 2019.

Hasibuan, A. et al., 2020. E-Business: Implementasi, Strategi dan Inovasi. Cetakan 1. Medan: Yayasan Kita Menulis.

Jati, R Wasisto. (2015). "Less Cash Society: Menakar Mode Konsumerisme Baru Kelas Menengah Indonesia". Jurnal Sosioteknologi. Vol 14. No 2.

Kesharwani, A. \& Shailendra, S. B. (2012). The Impact of Trust and Perceived Risk on the Internet Banking Adoption in India. International Journal of Bank Marketing, 30(4), 303-322. https://doi.org/10.1108/02652321211236923.

Khairi, Miftahul Rizqa, Gunawan, Eddy. (2019). Analisis Penggunaan Alat Pembayaran Menggunakan Kartu (APMK) dan E-Money Terhadap Konsumsi Masyarakat di Banda Aceh. Jurnal IImiah Mahasiswa Ekonomi Islam. Volume 1, Nomor 1, Maret.

Lau, G. T., \& Lee, S. H. (1999). Consumers' Trust in a Brand and the Link to Brand Loyalty. Journal of MarketFocused Management, 4(4), 341-370. https://doi.org/10.1023/A:1009886520142

Lin, C. and Nguyen, C. (2011) 'Exploring e-payment adoption in Vietnam and Taiwan', Journal of Computer Information Systems, 51(4), pp. 41-52. doi: 10.1080/08874417.2011.11645500.

Lintangsari, Nastiti Ninda, Nisaulfathona Hidayati, Yeni Purnamasari, Hilda Carolina, Wiangga Febranto. (2017). Analisis Pengaruh Instrumen Pembayaran Non-Tunai Terhadap Stabilitas Sistem Keuangan Di Indonesia. Semarang: UNDIP.

Ming, W. et al. (2016) 'Factors Affecting Consumers' Perception of Electronic Payment: an Empirical Analysis', Internet Research, 23(4), pp. 465-485.

Ndraha, Ester. (2019). Pengaruh Kemampuan Finansial dan Keamanan Terhadap Minat Penggunaan Produk Emoney (Studi Kasus) Pada Mahasiswa Universitas HKBP Nommensen Medan. Medan: Universitas HKBP Nommensen.

Nelasari. R.P., \& Cahyono, H. (2018). Pengaruh Sistem Transaksi Non Tunai Terhadap Tingkat Konsumsi Masyarakat Di Surabaya. Jurnal Ekonomi Islam, 1(2). 165-171.

Ramadani, Laila. (2016). Pengaruh Penggunaan Kartu Debit dan Uang Elektronik (E-Money) Terhadap Pengeluaran Konsumsi Mahasiswa. JESP-Vol.8, No.1 Maret 2016.

Ronny (2018) 'Customer participation in the creation and implementation of the service for internet banking', Journal of Economics, Business \& Accountancy Ventura, 20(3), pp. 309-317. doi: 10.14414/jebav.v20i3.763.

Rukmana, Rismawati D. (2016). Jurnal Dampak Perkembangan Pembayaran Non Tunai Terhadap Pertumbuhan Ekonomi Indonesia. Malang: UNBRAW.

Rumondang, A. et al. (2020). Fintech: Inovasi Sistem Keuangan di Era Digital. Medan: Yayasan Kita Menulis.

Sayekti, Fran \& Pulasna Putarta. (2016). Penerapan Technology Acceptance Model (TAM) Dalam Pengujian Model Penerimaan Sistem Informasi Keuangan Daerah. Jurnal Manajemen Teori dan Terapan. 9(3), 196-209.

Sekaran, Umar. 2006. Research Methods For Business. Edisi Keempat. Jakarta: Salemba Empat.

Setiani, Rahayu. (2018). Faktor- Faktor Yang Mempengaruhi Penggunaan Alat Pembayaran Non Tunai (Studi di Kota Purbalingga). Yogyakarta: Unviersitas Islam Indonesia. Skripsi.

Sugiyono. (2014). Metode Penelitian Kuantitatif Kualitatif dan R\&D. Bandung: Alfabeta. 
Wagner. (2009). Gaya Hidup "Shopping Mall" sebagai Bentuk Perilaku Konsumtif Pada Remaja di Perkotaan: Kasus Konsumen Remaja di Tiga One Stop Shopping Mall di Jakarta. Skripsi tidak diterbitkan. Institut Pertanian Bogor.

Wasiaturrahma, W., Wahyuningtyas, Y. T. and Ajija, S. R. (2019) 'Non Cash Payment and Demand for Real Money in Indonesia', Journal of Economics, Business \& Accountancy Ventura, 22(1), pp. 1-8. doi: 10.14414/jebav.v22i1.1575.

Wibowo, Setyo Ferry, Dede Rosmauli and Usep Suhud. 2015. Pengaruh Persepsi Manfaat, Persepsi Kemudahan, Fitur Layanan, dan Kepercayaan Terhadap Minat Menggunakan E-Money Card (Studi Pada Pengguna Jasa Commuterline di Jakarta). Jurnal Riset Manajemen Sains Indonesia, 6(1), pp. 440-456. https://doi.org/10.21009/JRMSI.006.1.06

www.bi.go.id. Diakses pada tanggal 10 Nopember 2019 